\title{
GREEN AESTHETICS IN CLOTHING
}

\author{
Normative beauty in commodities \\ Kirsi Niinimäki, \\ Aalto University, School of Arts, Design and Architecture
}

\subsection{ABSTRACT}

This paper presents an approach to understanding green aesthetics in clothing and design-forsustainability that unifies existing theories and describes aspects of green aesthetics. The aim of this paper is to define the dimensions of aesthetic perception in design and commodities, and while doing so the focus is on green aesthetics in clothing. Hence the approach is made on the basis of aesthetic discourse yet with a multidisciplinary view. The study first constructs an understanding of clothing aesthetics in general: the definition and understanding 'thin' aesthetics in the context of clothing, which combines product properties, multilayered pleasure experiences, and creativity elements. Secondly the study lays the ground for defining green aesthetics, a 'thick' aesthetic evaluation based on environmental aesthetics. Finally the study constructs a framework by which to approach green aesthetics in clothing. $O n$ the basis of this paper, parallels and synergies between green aesthetics in design objects and the definition of design-for-sustainability can be drawn, merging aesthetic attributes with environmental values. Hence the paper opens new views on normative beauty in commodities.

Keywords: Green aesthetics, clothing aesthetics, design-forsustainability, sustainable design, normative beauty.

\subsection{INTRODUCTION}

Recently discussion in aesthetics has broadened into the fields of everyday aesthetics and the aesthetic value of the environment. Yuriko Saito (2007, 52) proposes a new approach to aesthetics away from the art-centered approach, stating: “... we engage with the diverse aspects of the world aesthetically". She also suggests that when analyzing aesthetic aspects outside the art world, the use of the field's own terms inside the discipline itself is highly recommended. Furthermore she argues that through this widened approach we gain better understanding of the meaning of aesthetics in our everyday life, our judgments and preferences, and moreover how aesthetic issues profoundly affect all and everything. Ossi Naukkarinen (2001) distinguishes philosophical aesthetics from everyday aesthetics such that the former analyzes aesthetic dimensions while the latter tacitly describes and creates aesthetic dimensions and values. Richard Shusterman (1997, p. 103) argues (based on Dewey) that there is no reason to distinguish popular art from higher art according to aesthetic principles or evaluation. On this basis, he proposes, we can also demand high aesthetical quality from design artifacts. Hence it is most important to study contemporary aesthetics in the design discourse.

The contemporary design field itself strongly emphasizes visual attractiveness. Several studies have been published in the field of consumers' aesthetic preferences and how aesthetic dimensions can be used in the design field (e.g. Chattaraman \& Rudd, 2006; Rashid et al., 2004; Giannini et al., 2006; Hsiao et al., 2006; Crilly et al., 2004 and 2009). Nevertheless to a large extent the understanding of aesthetics in the design discipline encompasses only visual and functional levels, with no deeper philosophical discussion on aesthetic foundations in the world of artifacts. As sustainable design has emerged as a discipline of its own in recent years, the discussion on moral and ethical values has entered the design research field. While the central focus of this study is to increase eco-knowledge in the design field, it is fundamental to approach sustainable design also from a philosophical point of view. As Jason McLennan (2004) argues, sustainable design per se is a philosophical approach to the design field, not a visual and stylistic endeavor.

Yrjö Sepänmaa (1991) defines aesthetic beauty to be one of the principal forms of beauty. According to Sepänmaa other forms of beauty are moral, 
intellectual and functional beauty, which all can be linked to clothing and to sustainable design. Rather little is currently known about aesthetic dimensions in clothing in general. The concept of beauty is fundamental in clothing, yet the beauty of clothing is linked to its cultural, social and temporal context as well as bodily aspects. Therefore aesthetics and beauty as a concept is most complicated or even blurry and needs further research attention. As Sepänmaa (1980) states we need to develop the same kind of research and analysis systems, critiques and open discussions in environmental aesthetics that currently exists in the field of art. Furthermore Naukkarinen (1998) argues that we have to extend the aesthetic discussion from the art world to the world of everyday objects. Furthermore building robust knowledge of the green aesthetics of design objects is most important.

Therefore the paper develops the dimension of aesthetic evaluation in design and commodities, and while doing so the focus is on green aesthetics in clothing. Hence the topic is approached on the basis of aesthetic discourse, while incorporating research information from the fields of psychology, social psychology and sustainable design. Aesthetics has not been widely studied in the clothing context and therefore its definition is not established. The study therefore addresses, firstly, how the issue of aesthetics in clothing is to be approached in general, illustrating the various dimensions of aesthetic perception in clothing. Secondly the study investigates what green aesthetics is in the realm of clothing. In seeking to address these questions, the aim is to contribute to a better understanding of how to make possible aesthetic evaluation of commodities. John Hosper's (1946) thin and thick definition for aesthetics lays the ground for aesthetic understanding in this work. The study will thus elaborate upon the key concepts, first clothing aesthetics in general and secondly green aesthetics based on theories from environmental aesthetics. In the final section the dimensions and framework of green aesthetics in clothing are constructed.

\section{THIN AND THICK AESTHETICS}

John Hosper (1946) distinguishes two discrete meanings in aesthetical pleasantness: a thin and thick meaning. A 'thin' aesthetic is linked to a situation where we enjoy objects aesthetically, on the basic grounds of the apparel, its physical appearance, and its surface qualities. This appraisal also includes the form and construction of the object. $A$ 'thick' meaning adds to the aforementioned particular quality issues and values, which the object expresses or externalizes to the observer. According to Hosper thick aesthetics thus concerns objects that present life values: that is, general while deeper associations that are common to a larger group of individuals or communities (cited in Carlson 1976, p. 110). When we feed an aesthetic experience with our knowledge, we can talk about a thick aesthetic meaning. "Knowledge supports in some significant way the aesthetic qualities we discover and engage with" (Brady 2002, p. 120).

The first and most natural approach to studying the aesthetic evaluation of clothing is to address the attractiveness and beauty of the product, i.e. the thin aesthetical definition. Accordingly aesthetics is a property of a product while simultaneously it is the reaction or aesthetic expression these properties stimulate in the observer's mind and emotions. Therefore a thin aesthetic evaluation is a more common approach to clothing aesthetics. On the other hand a thick aesthetical meaning can be connected to eco-clothing and sustainable design, which intertwines aesthetic and ethical values. Thick aesthetic evaluation and understanding need a maturation of our taste, knowledge of the product's background, as well as an environmental value base; this will be further discussed below. First, the following section outlines specific ways to approach the aesthetics of clothing.

\section{AESTHETICS IN CLOTHING}

When aesthetic attributes, through which aesthetic perception traditionally occurs, are limited, we need to extend the properties of aesthetic evaluation.

Naukkarinen (1998) argues that traditional aesthetic dimensions, based on the art world, are well grounded but limited, and another approach to aesthetics needs to be reasoned. Hanson (1998) argues that there has been an antipathy to fashion in the tradition of philosophy, because fashion and clothing are inseparable from the body. The ideal concept of Beauty has traditionally been constructed such that the mind is superior to bodily aspects. However, the pleasure and experience clothes offer us is much wider than only visual pleasure.

Jon Lang $(1988$, p. 11) argues that in the design process the fundamental goal has always been beauty, the aesthetic and delightful aspects of the artifact. He also suggests approaching the aesthetic experience from three standpoints: the sensory, formal and symbolic interaction between the user and the built environment. This interaction between user and object forms the basis of the experience 
and pleasure that objects offer us. In design the attractiveness or beauty of the product is deeply interlinked with its functionality, its ease of use. Guy Sircello $(1975$, p. 73$)$ states that beauty is correlated to utility, suitability, appropriateness, fittingness and function. Accordingly certain objects, things or materials serve well for certain purposes, and therefore we consider them beautiful. Saito (2007, p. 26) argues that in our normal everyday interaction with practical objects, the practical and the aesthetics “.... are experienced as fully integrated and we lose some dimension of its aesthetic value if we surgically remove its functional value." Therefore when studying the aesthetics of design objects the interaction between user and object creates experience and pleasure, which translates into an evaluation process of the beauty of its use.

Katya Mandoki (2007) argues that business and marketing only use beauty and aesthetic aspects to attract a consumer's attention. The aim is to seduce the consumer into following ever-changing fashion trends and to make the consumer buy more. This argument is convincing: the aspect of beauty is significant when consumers are considering their own clothing choices. The clothing and fashion matrix is one of the fundamental human needs, and clothing and beauty can be considered a necessity (Martin, 1998).

Evidence of this can be seen in consumers' evaluation of the importance of beauty. Table I presents the results of an online consumer questionnaire carried out in spring 2009 in Finland (Niinimäki, 2009; Niinimäki, 2010). The link to the questionnaire was disseminated among design students at Helsinki Metropolia University of Applied Sciences and the University of Lapland. The link was also available to staff at the University of Art and Design Helsinki and on the following websites: Fashion Finland, Eettinen Kuluttaja (Ethical Consumer), Vihreät Vaatteet (Green Clothes), and Kierrätystehdas (Recycling Factory). A total of 246 respondents answered the questionnaire. The vast majority, $91.8 \%$, of the respondents, were women and $8.2 \%$ were men. The majority of the respondents were fairly young: $38.4 \%$ being 18 to 25 years old and $41.6 \%$ between 26 to 35 years old. It can be concluded that the young female standpoint dominated the responses in this data, yet young female consumers are also the biggest fashion consumer group. Through structured questions the meaning of clothing and attachment towards clothing were sought. Fourteen choices were offered in the 'meaning' questions and twelve choices were offered in the 'attachment' question. Respondents could choose more than one option. Both sections also offered open question where consumers could describe in their own words the meaning of clothing and the attributes connected to attachment to clothing. In these replies beauty stood in third place when consumers evaluated the meaning of clothing. When asked about the factors by which consumers become attached to textiles, beauty was ranked second. Beauty is therefore significant in clothing choices as well as in emotional bonding to garments. Furthermore the beauty aspects, the aesthetic criteria, are central when consumers are making the purchase decision in the field of apparel.

Table I. The meaning of beauty to consumers

\begin{tabular}{|l|l|}
\hline What clothes mean to me & $\begin{array}{l}\text { I become attached to textiles } \\
\text { and clothing, because they } \\
\text { are } \\
\text { Respondents \% }\end{array}$ \\
\hline practicality 94 & practical/functional 97 \\
\hline own identity 91 & beautiful 94 \\
\hline beauty 89 & made with high quality 91 \\
\hline
\end{tabular}

How then we can approach clothing aesthetics? Naukkarinen (1998) argues that some things are easier to aestheticize than others. "The colors of clothes are a typical example of properties that can easily be turned into aesthetic ones.... On the other hand, how ... a fabric feels or smells is not typically taken as an aesthetic issue..." (Naukkarinen 1998, p. 36). We learn to identify and comprehend many objects at a sensory level, and these learned aesthetic perceptions are a basic part of our culture as are perception of colors and forms. Quite often these simple and easily absorbed factors are associated with more complex ones such as the concept of beauty or ugliness (Naukkarinen 2007, p. 50). Hence we make a quick evaluation of the beauty of the apparel based on surface qualities and confuse it with deeper aesthetics.

“What is meant by aesthetic depends heavily on the context, but one possibility is to associate it with simple and direct [visual] perceptions and the pleasure we gain from them" (Naukkarinen 2007, p. 50). To ground this, we have to understand the many levels of pleasure connected to the product world. Lionel Tiger (1992, cited by Patrick Jordan 2000) argues that objects offer us four types of pleasure: Physio-pleasure, Socio-pleasure, Psychopleasure and Ideo-pleasure. Physio-pleasure is the link to the body and pleasures derived from the sensory system. These include the touch and 
feeling of sensual pleasure and tactile and olfactory properties in the object. Socio-pleasure emerges through the enjoyment derived from relationships with others and with society. In the context of clothing socio-pleasure means e.g. the social acceptance and appropriateness the wearer hopes to gain through clothing choices. Psycho-pleasure links the experience the object offers us with cognitive and emotional reactions such as product satisfaction. We feel pretty when wearing a certain dress, or the dress gives us positive feedback in the form of energy or happiness. Ideo-pleasure is linked to values: that is, it simultaneously relates to the aesthetics of a product and the values that a product represents. “For example a product made from bio-degradable materials might be seen as embodying the value ideo-pleasure to those who are particularly concerned about environmental issues" (Jordan 2000, p. 14).

In exploring the aesthetic dimensions in clothing, Table II is constructed based on the pleasures clothing offers us. Are these pleasures directly associated with the basis of the aesthetic experience? Can we ground the aesthetic of clothing on a general sense of appreciation of clothing and valuation of its quality? In Susan Kaiser's (1990) psycho-sociological theory of clothing, time, fashion and aesthetic aspects belong to a cultural contextual approach to clothing. Other conceptual levels from which to approach clothing are e.g. group association, social situation, immediate body space, personal characteristics, kinetic interaction and garment/ body interaction, according to Kaiser. All these aforementioned levels also offer pleasures, but whether we can define them as aesthetic pleasures needs further attention. Paul Hekkert (2006) states that experiences with products consist of three levels: aesthetic, understanding and emotional. He suggests that only some part of the experience should be considered as aesthetic, and the rest of the experience is in fact linked to the human mind, that is, the observer's cognition and emotion. This approach is a rather narrowing way to understand everyday aesthetics and the aesthetic experience per se.

A quick and simple evaluation of clothing can be made according to attractiveness, color, fit, form and style of the clothing. These factors are grounded in cultural as well personal preferences, the wearer's age and societal situation, but also strongly to the temporal level: present trends and fashion. However, there is a more complex evaluation procedure of clothing that is intertwined with social situations and group association, and this is also the case in fashion and clothing. In clothing beauty and the approval of others both play an important role. Someone may have no particular opinion on clothing choices and select 'neutral' apparel, yet he/she still does not want to look 'ugly'.

Therefore the pleasure of clothing is linked to acceptance of others, social situations and the experience created by those social situations. Minna Uotila (1995) states that clothes are not only objects: they are also acts. Therefore clothes must also be studied as a creation process itself. The creator in

Table II. Dimensions of pleasure with clothing based on Tiger (1992)

\begin{tabular}{|l|l|l|l|}
\hline \multicolumn{2}{|l|}{ Dimensions of pleasure with clothing } & Psycho-pleasure & Ideo-pleasure \\
\hline Physio-pleasure & Socio-pleasure & $\begin{array}{l}\text { product satisfaction, e.g. } \\
\text { beauty of use }\end{array}$ & environ-mental awareness \\
kinetic dimension & social situations & $\begin{array}{l}\text { experience, also visual expe- } \\
\text { rience }\end{array}$ & $\begin{array}{l}\text { preferring ecological, ethical } \\
\text { and sustainable design }\end{array}$ \\
tactile dimension & $\begin{array}{l}\text { acceptance, } \\
\text { appropri- } \\
\text { ateness appropriateness } \\
\text { appropriateness }\end{array}$ & $\begin{array}{l}\text { interaction between the prod- } \\
\text { act and user's emotion }\end{array}$ & $\begin{array}{l}\text { envical consumption } \\
\text { entrontal awareness }\end{array}$ \\
\hline
\end{tabular}




\begin{tabular}{|c|c|c|c|c|}
\hline $\begin{array}{l}\text { Visual and } \\
\text { form qualties }\end{array}$ & Social dimensions & Sensory dimensions & Creativity dimensions & $\begin{array}{l}\text { Properties of } \\
\text { technical skillfulness }\end{array}$ \\
\hline color & social situations & kinetic experience & $\begin{array}{l}\text { uniqueness, creativity in } \\
\text { design }\end{array}$ & pattern, fit \\
\hline style & approval & tactile experience & fashion as art & manufacturing \\
\hline $\begin{array}{l}\text { material } \\
\text { cut, fit }\end{array}$ & $\begin{array}{l}\text { experience } \\
\text { interaction }\end{array}$ & $\begin{array}{l}\text { garment/body interaction } \\
\text { touch, smell etc. }\end{array}$ & $\begin{array}{l}\text { wearer's creativity, } \\
\text { fashion as act }\end{array}$ & \\
\hline functionality in use & & & & \\
\hline
\end{tabular}

clothing is not only the designer but also the wearer. Mandoki (2007, p. 175) maintains that when aesthetics are concerned, we are dealing with social interaction processes. Furthermore the aesthetic level is dominant in communication with others in social situations, because aesthetics affects the way the message is displayed or interpreted in a communicative exchange process. In other words we communicate silently with others through our appearance.

Naukkarinen (2007, p. 51) suggests that when making an aesthetic evaluation technical skillfulness could also be taken into account. According to Sircello $(1975$, p. 56) elegance is one attribute from which to approach aesthetics, and elegance can be found in, for example, the "...fineness in the fabrics of one's dress, in the workmanship of one's clothing". He also states that intellectual beauty is something that respects extraordinary skillfulness. Hence the interpretation can be made that aesthetic dimensions in design objects may also include the technical realization and manufacturing outcomes. Cheap mass-manufactured clothes do not have this level of skillful technical realization, unlike a uniquely tailored suit or evening dress of high quality. The wearer can experience aesthetic satisfaction with a suit or evening dress that fits him/her perfectly and is made of high quality material, using a high level of technical skill.

We experience beauty in clothing in a multisensory way. Mandoki (2007, p. 63) points out that "[s] ense is the raw material of subjectivity, and exists not only in the so-called body organs, but also as a mental sense, namely the emotional, relational, and sensorial meaning." Judging the beauty of clothing and the aesthetical experience must thereby also include the kinetic interaction and garment/body interaction. The attractiveness of clothing is not only visual: styles, fit and color as well experiences of a pleasant touch on the skin, that is, softness, airiness of the material, or the weight of the material against our body and skin, are all important factors when evaluating clothes, especially during longer use periods or at a sensual level. The kinesthetic experience links body awareness and muscular tension and movement with the environment (Berleant, 1992). A pleasant kinetic and tactile interaction can be seen as an objective, and therefore it is possible to consider these as dimensions in an aesthetic experience with clothing. The dress can be made of silk, which offers a pleasant, airy touch on the skin, feels sensual against our body when moving, and offers a pleasant aroma. The same dress can be beautiful in design, style and color, and it can be uniquely designed and tailored just for the wearer. This kind of dress will be noticed by others, and the wearer will receive positive feedback in social situations; over time and through positive use experiences, the wearer will form a deep engagement with the product.

Table III outlines the various factors involved when defining the general aesthetic attributes in clothing. Creativity in this context means the sense of novelty that is always present in clothing and fashion design. A fashion designer creates a new collection 
twice or even four times a year. Can this be aesthetic creativity, which, according to Naukkarinen (2007, p. 53), means "creating a new solution never tried before"? Clothing design is generally based on following and interlinking trends and styles, and rarely does something completely unique happen in the area of clothing design. Some designers however have developed a new, distinct and personal style in fashion, an act that could be considered aesthetic creativity. One example is Issey Miyake, who created a radically new clothing concept in the 1980s: the one-size dress made with one cut piece of fabric. Miyake's style is simple but this was quite revolutionary at that time because it renewed the whole concept of making clothes based on traditional measuring and model patterns. Miyake has also skillfully combined creativity, novelty in technical skillfulness and innovation, and high quality in design, style and materials.

The notion of creativity can also be seen in how the consumer interprets fashion in their own way or even in creating their own styles when combining different pieces of clothing to create a unique look. Uotila (1995) argues that a consumer creates a "fashion act" when modifying fashion styles and rules to create an individual look according to their own inner values, emotions and identity. Hence highly unique and visually beautiful, interesting and even odd personal deviations from fashion styles can be considered "fashion acts", which may also be defined as aesthetic creativity.

\section{Furthermore a short explanation on how design} creativity is connected to the art world is needed. Traditionally there has been a clear separation between the art and fashion fields, but there have been instances where fashion has penetrated into the art world since the 1960s. In these instances a dress has been a vehicle with which to express artistic identity and intention. Even some fashion shows may be constructed in an artistic way, where all elements together create a unique and aesthetical experience. Garments may come close to sculpture or a space installation when exhibited in art museums. The contexts where the garments are presented are also crucial. However, even in these artistic instances, the other aspects of clothing are less important, such as functionality and fit. (Pöppönen, 20.12.2009) Naukkarinen (2001) distinguishes haute couture and fashion from "everyday" clothes. He argues that the former is strongly linked to the art world and its aesthetical dimensions, while the latter needs a different aesthetic approach.
This section has laid the grounds for a general understanding of clothing aesthetics, and it approached aesthetic evaluation as a multilayered experience, which combines different pleasures, bodily aspects, product properties and the wearer's emotional experiences in the cultural and social context. This can be seen, as previously explained, as a 'thin' aesthetic evaluation. The next section will unpack the notion of 'thick' aesthetic evaluation as well as the definition of green aesthetics based on environmental aesthetics.

\section{GREEN AESTHETICS}

While the discipline of green aesthetics is still emerging, discussion on it can be grounded on the basis of environmental aesthetics; nevertheless even environmental aesthetics is rather new and still developing as a discipline of its own. Arnold Berleant (1998, p. 114) argues that the environmental experience in aesthetics is not only visual; it involves all experiences through our sensory system. It is suggested that the environmental experience itself includes the following factors: space, mass, volume, time, movement, color, light, smell, sound, tactility, kinesthesia, pattern, order and meaning. These factors are added to the normative dimension of environmental evaluation in environmental aesthetics.

This normative dimension of green aesthetics needs a closer look. Sircello $(1975$, p. 79$)$ writes about the goodness that beautiful objects may possess. Goodness means that something is beneficial to or for something. Accordingly, the interpretation can be made that green aesthetics is something that is good and beneficial for the environment and sustainable development. Sircello also states based on Immanuel Kant that beauty can be free or dependent, adherent, and he points out that up until the time of writing (the 1970s) philosophers had not been interested in adherent beauty. Environmental problems have changed this situation, and the discipline of environmental aesthetics has been developing since the 1970s. The concept of green aesthetics has thereby emerged on this basis.

In environmental aesthetics, the visual and other sensory systems are not the only actors in the aesthetic experience. In environmental aesthetics a deep dive into ecological values has to be made. Berleant suggests $(2002$, p. 16) that "aesthetic value may provide a foundation of intrinsic value for the ethical values in the environment." There is thus a relationship between ethics and aesthetics in environmental aesthetics as well as in green aesthetics 
that is fundamental. Environmental values penetrate the aesthetic evaluation when the observer is making an environmental aesthetical judgment. The object under evaluation also includes moral values, or the observer reflects upon the aesthetic evaluation against ecological values. Jussi Kotkavirta $(2003$, p. 97) argues that "...the aesthetic and the ethical are different but connected with each other." He also maintains that all that is aesthetically valued is not at the same time ethically appreciated. And the reverse is true: all that is ethically interesting does not necessarily embody aesthetical attributes. Victor Papanek (1995, p. 49) quotes Jean-Luc Godard thus: "It may be true that one has to choose between ethics and aesthetics, but whichever one chooses, one will always find the other at the end of the road." Berleant (1992) argues that the moral and aesthetic can join together, and when achieving a breakthrough in ecological development it is possible to achieve the same also at aesthetic and moral levels. This is a strong, positive and normative statement regarding sustainable futures and what choices to make to promote environmentalism.

Berleant (2002) argues that environmental aesthetics points out important but often overlooked values in ecological thinking, and it thereby offers ways to rethink the conventional aesthetical explanations. Aesthetic qualities are usually identified from surface qualities. Furthermore there are usually two separate categories of sensory perception. Distance receptors can sense using sight and hearing to gain an aesthetic experience associated with ideal Beauty. Contact receptors engender a tactile experience, which is linked to e.g. surface texture, pressure, and temperature, according to Berleant. These aspects are most important when we extend the concept of aesthetics to concern the world of artifacts and their aesthetic evaluation. Berleant $(2002$, p. 9) also argues that "aesthetic perception is never purely a physical sensation and never discrete and timeless. It is always contextual, mediated by the variety of the conditions and influences that shape all experiences." He points out that our aesthetic perception and judgment are always cultural; therefore environmental aesthetics must also involve cultural aesthetics, which is most important when defining or judging the aesthetics of design objects.

Berleant and Carlson (2007, p. 207) claim that the strict meaning of beauty and aesthetic judgment implies "... a thorough background check and consider[ation of the object's] projected consequences." Walker (2009) points out that in the area of sustainable design, we have to evaluate the product as a whole and go beyond appearance, considering the production, materials, use and afteruse, and furthermore its meaning and contribution. Papanek (1995, p. 57) talks about the spiritual values in design in the following way: "There is a point at which beauty and high utility through good design interconnect. If both conditions exist simultaneously in an object, and are furthermore clear expressions of the social intent of the people who designed it, it is possible to speak of the spiritual in design." This spiritual value in design comes close to the definition of green aesthetics; furthermore Papanek points out that when evaluating design one criterion could be the dimension through which design significantly contributes to the sustainability of the environment. The concept of design-for-sustainability has emerged on the basis of this thinking.

There is therefore not only the aesthetical aspect but also the moral-aesthetical argumentation in green aesthetics, which merges moral values and aesthetic sensitivity. Carlson (1976) offers the example of plastic trees. Plastic trees can be as attractive as natural ones according to the thin aesthetic meaning. According to thick aesthetics, however, plastic can be judged as aesthetically unpleasant, ugly, on the grounds of the life value the plastic expresses.

Jordan (2002) believes that personal ideologies, such as environmental concerns, affect the aesthetic appreciation of products. As the saying goes, beauty is in the eye of the beholder, but the eye notices what it has been taught to behold. Saito (2007) asks if it is possible to redirect aesthetic preferences towards better environmental solutions; that is, through education aesthetic taste can be directed to appreciate environmental values. As described earlier the thick meaning in aesthetic evaluation can include a deeper evaluation entailing quality as well as morality. Hence thick aesthetics include life values supporting sustainable development. Saito argues that "a new aesthetic sensibility should be cultivated to educate us about the consequences of our aesthetic preferences" (2007, p. 78). Brady (2002) argues that when feeding new knowledge into an aesthetic experience, it is possible to rethink and re-evaluate aesthetic qualities. Stuart Walker (2009) argues that knowledge about an artifact affects the way observers see, experience and respond to the object.

Ronald Moore (2008, p. 239) argues that "[i]t is a sign of maturity in general - moral, political, and social no less than aesthetics - that feelings and thought stratify." He also points out that 
responsibility helps us to develop a mature appreciation for our normative response in aesthetics. Moore describes the order of responses to natural beauty. The first response is an immediate pleased reaction, where the sensory element is dominant. The second-order response is reflective awareness, which needs a cognitive reaction and series of reframing and reflective inquiries. At the third level the pleasure felt moves into commitment (evidentiary consideration), and the fourth level entails an analogical extension, according to Moore. He suggests that at this fourth level the aesthetic values can connect with other values.

On this basis green aesthetics can be considered a normative way to evaluate design objects by combining aesthetic values with environmental values, and the aim, while doing so, is to promote sustainable futures (Saito, 2007). Hence it is not possible to consider only the evaluation attributes proposed in the previous section; rather new factors with which to evaluate the green aesthetics in the clothing field must be formulated, while the aesthetic and moral interests should be so intertwined that they are hard to separate. Brady (2002) suggests that we favor moral values over aesthetic ones. Nevertheless in clothing this is not such an easy process since in appearance the most fundamental attribute is beauty.

Norman (2005, p. 38) argues that "[s]ophistication often brings with it a peculiar disdain for popular appeal, where the very aspects of a design that make it appeal to many people distress some intellectuals." As previously stated, a new kind of knowledge and understanding is needed in green aesthetic evaluation. If we interpret Norman's argument, we could conclude that the current appeal of popular clothing design and fashion will not satisfy environmentally sophisticated minds. The cheap, low quality, mass-manufactured clothing presently available and ever-changing fashion styles do not correspond to ecological balance and environmental values in reaching sustainable futures. On the contrary: an environmentally conscious consumer does not follow fast cycles of fashion trends but instead tries to make environmentally and ethically better consumption choices.

In green aesthetics regarding artifacts scientific information is needed to transform a negative aesthetic response into a positive response, according to Saito (2007). Nonetheless the need for a visually beautiful appearance is the most important factor in the field of clothing. Eco-clothes have to fulfill the customer's concept of beauty in order to be considered attractive. Hence eco-clothing has to be attractive, a good fit, and visually pleasant even if it is designed and manufactured according to sustainable principles. For sustainable development the best way to promote sustainable futures is to consume less. Hence the best way to try to assure sustainable development involves recycling more, using clothes until they are completely worn out, and avoiding excessive water washing and ironing. This kind of sustainable scenario for clothes, where they are old, torn and patched up, dirty and wrinkled, would in practice correspond to environmental values but most certainly would not fulfill our need for beauty or social norms in appropriateness. In other words green but at the same time antiaesthetic, ugly fashion is not possible. Saito argues $(2007$, p. 85$)$ that " $[\mathrm{g}]$ reen aesthetics regarding artifacts has an additional mission: to render initially attractive objects not so aesthetically positive if they are environmentally harmful." John Dewey (1925) states that we can explore changes in our valuing observation when a beautiful, aesthetic object is exposed to be something other than what we believed it to be. The most effective way to promote environmental values is to link one's own aesthetical preferences with an attraction to green aesthetics and to guide design aesthetics in general to promote a sustainable world: that is, aligning aesthetics with environmentalism (Berleant \& Carlson, 2007). This needs a maturing process, further research and consumer and designer education.

\section{GREEN AESTHETICS IN CLOTHING}

The final section of this paper develops further the aesthetic dimension of green aesthetics in clothing. The approach is thus on the basis of aesthetic discourse yet in a more explorative than argumentative way, unifying the issues previously discussed with sustainable design values.

When attempting to pinpoint opportunities for green aesthetics in clothing, it is necessary to study the possibilities for green dimensions in artifacts in general. Saito (2007) shows several ways to approach everyday objects from a green aesthetic point of view. The first is minimalism, which interlinks with such terms as reduce, reuse and recycle from the discipline of sustainable design. In the context of clothing design all these terms are useful. Reduce could be understood as the aim to reduce environmental impact in all stages of manufacturing and transportation, and even in the use phase. This also means eco-efficiency in sustainable design. Reuse and recycle are good principles for product design. The cradle-to-cradle principle advises designers to 
include multiple lifecycles for the object and the material of which it is made (McDonough \& Braungart, 2002). Recycling and multiple lifecycles are possible if the product does not combine too many materials and it is simple enough for a separation process after use; i.e. it is possible to be disassembled and recycled. Naukkarinen (2001) suggests that minimalism in everyday clothes means simplicity. This can interpreted as being muted in style and color. Clothing design based on classical styles and colors, which do not change rapidly following fads, can be used longer and is thereby more sustainable. This also refers to the second factor, which we will describe next.

The second dimension Saito (2007) suggests is the product's durability and longevity. This is best achieved through high quality and classical design. There are examples of this kind of eco-design: for example, Anne Linnonmaa's Eco-Fashion collection (the Anne Linnonmaa ecological fashion firm was operational 1993-2007). Linnonmaa's collection was made of eco-materials, with high quality standards and classical styles and colors, and it was even produced in Finland. The basic collection was added to slowly with new pieces and colors that could be combined with previous Anne Linnonmaa clothes. This lessened the consumers' need to renew their whole wardrobe according to changing trends and fashion. Longevity can be achieved by creating opportunities for upgrading and reparability in products and by choosing materials that age well. This is most critical in clothing, because often we want new clothes not only because of changing fashions but because the material or the outfit is looking worn out. This means that designers and consumers should prefer high quality materials and carefully consider the prints and colors as well as the textile techniques (printing or weaving) used in order to bring about the best result in pleasant and aesthetical ageing. The aging process of, for example, real leather is more aesthetically pleasant than artificial leather.

Saito (2007) highlights the following dimensions in green aesthetics: fittingness, appropriateness and site-specificity. The last refers to e.g. locally available materials, according to Saito. It can also mean local manufacturing and thus less transport. In the clothing business localness is currently not easy to ensure, as cultivation, material and manufacturing processes are global, fragmented and mainly located in lower-cost countries. Site-specificity also means respect for diversity and creating less monoculture. Hence the work in the field of new eco-materials is significant. Fittingness and appropriateness refers to the suitability for use, e.g. for workwear or in certain social situations, as well as the cultural and temporal context. A good fit and appropriateness could also increase the wearer's satisfaction and thereby ensure an extended lifespan of the product.

Designer Anna Ruohonen has created a long lasting collection, "Black Classics", where each garment is made according to the wearer's individual measurements. This approach better ensures perfect fit, deep product satisfaction and through high quality in material and manufacturing longer lasting products. Ruohonen's design strategy is to create classical and durable design, high quality garments yet with a creative touch (see Figure 1). This approach also respects the environment, as no surplus production is needed; the production is made according to orders only.

Saito (2007) argues that one important value to take into account in green aesthetics is the health aspect, describing the environment and its effects on human health. This can be interpreted in the context of design to be a health issue in design, manufacturing and use. The clothing industry in Asian countries has a huge environmental impact, for example. Some materials (such as cotton) may even include chemicals hazardous to the wearer, e.g. pesticides. To promote these health aspects in clothing, it would be beneficial to choose clothes that have an eco-label such as the European Union eco-label.

Saito (2007) further expands the scope of green aesthetics by including a caring and sensitive attitude, which she describes as the most general aesthetic value expressed by green objects. A responsible attitude towards the environment and objects we possess is fundamental. Such an attitude leads to ethical consumption, that is, consuming less, but that which is durable and repairable. A caring attitude and increased sense of responsibility is also intertwined with product attachment. A positive feeling for green design is something to aim for, because positive emotions create commitment and bonding to these artifacts, which will be taken care of and cherished. Recent research in the field of emotional design offers designers several opportunities to embed these emotional bonding possibilities into products. We ascribe value to a product if we can experience enjoyment with it, it offers us interpersonal ties, and it becomes linked to the construction of our identity. Emotional intensity is greatest 
towards the objects that provide, for example, deep sensory and aesthetic satisfaction. (e.g. Koskinen \& Battarbee, 2003)

Jordan (2000) argues that one pleasure artifacts can provide, as previously mentioned, is ideo-pleasure, which is linked to the user's values such as environmental awareness as well as appreciation of aesthetics. All pleasures can intertwine while using the product, and through this interaction and pleasure an engagement with the product is created. This is especially meaningful if the user forms a longlasting attachment to the object. In green aesthetics both aesthetic and environmental values are connected, as mentioned, and the previous discussion is summed up in Table IV. The first dimension still takes into account the pure visual and sensory pleasure, because beauty is always fundamental in appearance. The other factors lean strongly on Saito's arguments, and interpretations are made in order to add knowledge to the sustainable clothing field. In these attributes both aesthetic values and values and principles from sustainable design combine. Many areas overlap, and an individual attribute may fall into several categories simultaneously. Aesthetics here is approached from a wide perspective, but this approach still leaves outside several choices the designer must make during the product development process. Nevertheless this builds a framework for green aesthetics in clothing and it is a contribution to fill the gap in our knowledge when approaching sustainable design from a philosophical point of view. According to this study the definition of green aesthetics in clothing merges with clothing design-for-sustainability.

“Definitions, be they more or less near the truth, can in particular situations help percipients to direct their attention, but they cannot force percipients to see beauty" (Kuisma 2006, p. 73). The concept of green aesthetics is normative, and it enables us to cultivate and mature our aesthetical preferences. Green aesthetics offers the possibility to combine environmental values with aesthetic experiences. As McLennan (2004) outlines, while the current rather young sustainable design field is developing

Table IV. Green aesthetics in clothing

\begin{tabular}{|c|c|c|c|c|c|c|}
\hline $\begin{array}{l}\text { Visual and } \\
\text { form qualities }\end{array}$ & Minimalism & Durability & $\begin{array}{l}\text { Site-speci- } \\
\text { ficity }\end{array}$ & $\begin{array}{l}\text { Fittingness } \\
\text { Appropriate- } \\
\text { ness }\end{array}$ & Health & $\begin{array}{l}\text { Caring and } \\
\text { sensitive } \\
\text { attitude }\end{array}$ \\
\hline $\begin{array}{l}\text { color } \\
\text { style } \\
\text { material } \\
\text { cut, fit } \\
\text { functionality }\end{array}$ & $\begin{array}{l}\text { reducing } \\
\text { eco-efficiency } \\
\text { reusing } \\
\text { recycling } \\
\text { multi-lifecy- } \\
\text { cles } \\
\text { classical } \\
\text { design } \\
\text { timeless } \\
\text { materials and } \\
\text { colors }\end{array}$ & $\begin{array}{l}\text { longevity } \\
\text { high quality } \\
\text { long lasting } \\
\text { design and } \\
\text { style } \\
\text { material dura- } \\
\text { bility } \\
\text { ageing aes- } \\
\text { thetically } \\
\text { reparability }\end{array}$ & $\begin{array}{l}\text { rejecting } \\
\text { monoculture } \\
\text { respect for } \\
\text { diversity } \\
\text { use of differ- } \\
\text { ent materials, } \\
\text { especially } \\
\text { eco-ones } \\
\text { developing } \\
\text { diversity in } \\
\text { materials } \\
\text { supporting } \\
\text { different } \\
\text { manufacturing } \\
\text { processes and } \\
\text { small scale } \\
\text { manufacturing }\end{array}$ & $\begin{array}{l}\text { suitability for } \\
\text { use } \\
\text { suitability } \\
\text { for social } \\
\text { situation }\end{array}$ & $\begin{array}{l}\text { environmental } \\
\text { impact in man- } \\
\text { ufacturing } \\
\text { eco-materials } \\
\text { eco-labels } \\
\text { water footprint } \\
\text { carbon foot- } \\
\text { print } \\
\text { ethical manu- } \\
\text { facturing } \\
\text { safe to use }\end{array}$ & $\begin{array}{l}\text { responsible } \\
\text { attitude } \\
\text { extended } \\
\text { product } \\
\text { lifespan } \\
\text { care and } \\
\text { repairing } \\
\text { satisfied expe- } \\
\text { rience } \\
\text { deep product } \\
\text { attachment }\end{array}$ \\
\hline
\end{tabular}


and maturing further, it offers us successful models for combining beauty and high performance in order to achieve successful green aesthetics and satisfying product experience. Papanek (1995, p. 70) summed this up thus: "[t]he rise of a new aesthetic that is formed by environmental and ecological considerations will be unpredictable in its shapes, forms, colors, textures and varieties and - at the same time - enormously exciting."

\section{CONCLUSIONS}

Beauty and aesthetic dimensions are the most significant when consumers are choosing his/ her clothing and designers are creating new objects. Nevertheless current consumption is on unsustainable ground, and a new ethical consumer culture and radical changes towards sustainability are needed. Green aesthetics offers the possibility to combine environmental values with aesthetic experiences.

Aesthetic perception is never only a pure physical or psychological experience, because it is always connected to time and culture. The concept of green aesthetics adds to this the possibility to embody moral and environmental values in aesthetic preferences. A better understanding of how aesthetic and environmental values are experienced forms a solid basis for the evaluation process through which the observer can evaluate his/her own aesthetic preferences in the field of design and commodities. This profoundly new way to align design-for-sustainability and green aesthetics advances our understanding of material culture. Green aesthetics is normative, and it enables us to cultivate our aesthetical preferences according to sustainable values. Furthermore it extends the possibilities to evaluate design objects and commodities on the ground of aesthetics.

This study has presented an approach to green aesthetics in clothing and design-for-sustainability that describes aspects of green aesthetics relevant to the designer and the consumer. The study first constructed an understanding of clothing aesthetics in general: the thin aesthetic definition in the context of clothing, which combines product properties, multilayered pleasure experiences and creativity aspects. Secondly the study grounded the definition for green aesthetics, the thick aesthetic evaluation based on environmental aesthetics. Finally the study constructed a framework with which to approach green aesthetics in clothing. On the basis of this paper parallels between green aesthetics in design objects and the definition of design-for-sustainability can be drawn by merging aesthetic with environmental values and attributes. The sustainable design process is normative, and it implies environmentalism. Sustainable design can offer the user positive aesthetic experiences and deep and lasting product satisfaction, and it should captivate the consumer's imagination in a sustainable way. Knowledge about green aesthetics and normative beauty helps us to develop our aesthetic evaluation in commodities in the context of sustainable development.

\section{ACKNOWLEDGEMENTS}

The author wishes to thank Vice Dean Ossi Naukkarinen (Aalto University, School of Arts, Design and Architecture) for his insightful comments on earlier versions of this article.

\section{REFERENCES}

Berleant, A. (1992). The aesthetics of environment. Philadelphia: Temple University Press.

Berleant, A. (1998). Environmental aesthetics. In M. Kelly (Ed.), Encyclopedia of aesthetics (Pp.114120). Oxford: Oxford University Press.

Berleant, A. (2002). Introduction: art, environment and the shaping of experience. In A. Berleant (Ed.), Environment and the arts: perspectives on environmental aesthetics (Pp. 1-21). Burlington: Ashgate Publishing Limited.

Berleant, A., \& Carlson, A. (2007). The aesthetics of human environments. Canada: Broadview Press.

Brady, E. (2002). Aesthetics, ethics and the natural environment. In A. Berleant (Ed.), Environment and the arts: perspectives on environmental aesthetics (Pp. 113-126). Burlington, Usa: Ashgate Publishing Limited.

Carlson, A. (1976). Ympäristöestetiikka ja esteettisen kasvatuksen dilemma. In Y. Sepänmaa (Ed.), (1994). Alligaattorin hymy. Ympäristöestetiikan uusi aalto (Pp. 105-117). Finnish Translation Leevi Leht. Jyväskylä: Gummerus.

Chattaram, V., \& Rudd, N. A. (2006). Preferences for aesthetic attributes in clothing as a function of body image, body cathexis and body size. Clothing and Textiles Research Journal, 24 (1), 46-61.

Crilly, N. (2004). Seeing things: consumer response to the visual domain in product design. Design Studies 25, 547-577.

Crilly, N. (2009). Shaping things: intended consumer response and the other determinants of product form. Design Studies 30, 224-254. 
Dewey, J. (1925). Art as experience. Chicago: Open Court Publishing.

Giannini, F., \& Monti, M., \& Podehl, G. (2006). Aesthetic-driven tools for industrial design. Journal Of Engineering Design, 17(3), 193-215.

Hanson, K. (1998). Fashion and philosophy. In M. Kelly (Ed.), Encyclopedia of aesthetics (Pp.157160). Oxford: Oxford University Press.

Hekkert, P. (2006). Design aesthetics: principles of pleasure in design. Psychology Sciences, 48(2):157-172.

Hsiao, S., \& Chiu. F., \& Chen, C. S. (2008). Applying aesthetics measurement to product design. Industrial Economics, 38, 910-920.

Jordan, P. (2000). Designing pleasurable products: an introduction to the new human factors. London: Taylor And Francis.

Kaiser, S. (1990). The social psychology of clothing: symbolic appearances in context (2nd ed.). USA: Macmillan Publishing Company.

Koskinen, I., \& Battarbee, K. (2003). Introduction to user experience and empathic design. In I. Koskinen \& K. Battarbee \& T. Mattelmäki (Eds.), Empathic design: user experience in product design. Helsinki: Edita.

Kotkavirta, J. (2003). Aesthetic experience and intrinsic values. In A. Haapala \& 0. Kuisma (Eds.), Aesthetic experience and the ethical dimension. Essays on moral problems in aesthetics (Pp. 8398). Helsinki: Philosophical Society of Finland.

Kuisma, 0. (2003). Plotinus: beauty, virtue, and aesthetic experience. In A. Haapala \& 0 . Kuisma (Eds.), Aesthetic experience and the ethical dimension. Essays on moral problems in aesthetics (Pp. 65-82). Helsinki: Philosophical Society Of Finland.

Lang, J. (1988). Symbolic aesthetics in architecture: toward a research agenda. In J. L. Nasar (Ed.) Environmental aesthetics. Theory, research \& application (Pp.11-26). Cambridge: Cambridge University Press.

Mandoki, K. (2007). Everyday aesthetics: prosaics, the play of culture and social identities. Hampshire: Ashgate.

Martin, R. (1998). Fashion as art. In M. Kelly (Ed.), Encyclopedia of aesthetics (Pp.154-157). Oxford: Oxford University Press.

Mcdonough, W., \& Braungart, M. (2002). Cradle to cradle. Remaking the way we make things. New York: North Point Press.

Mclennan, J.F. (2004). The philosophy of sustainable design. Canada: Ecotone.
Moore, R. (2008). Natural beauty: a theory of aesthetics beyond arts. Ontario: Broadview Press.

Naukkarinen, 0. (1998). Aesthetics of the unavoidable: aesthetic variations in human appearance. Lahti: International Institute Of Applied Aesthetics.

Naukkarinen, 0. (2007). Art of the environment. Helsinki: Okka Foundation For Teaching, Education And Personal Development.

Niinimäki, K. (2009). Consumer values and ecofashion in the future. In M. Koskela, \& M. Vinnari, (Eds.). Future of the consumer society. Proceedings of the conference "future of the consumer society", 28-29 may 2009, tampere, finland (Pp.125-134). Finland Futures Research Centre, Turku School Of Economics. Available at: http:// www.tse.fi/fi/yksikot/erillislaitokset/tutu/documents/publications/ebook_2009-7.pdf [Accessed 2 November 2009]

Niinimäki, K. (2010). Eco-clothing, consumer identity and ideology. Journal Of Sustainable Development. 18: Forthcoming.

Norman, D. (2005). Emotional design: why we love (or hate) everyday things. New York: Basic Books.

Papanek, V. (1995). The green imperative: ecology and ethics in design and architecture. New York: Thames And Hudson.

Pöppönen, H. (2009). Muoti valloittaa taiteen pelikentän. Boijmans-museon näyttely tutkii muodin ja kuvataiteen suhdetta. Helsingin Sanomat 20.12. 2009.

Rashid, A., \& Mac Donald, B. J., \& Hashmi, M. S. J. (2004). Evaluation of the aesthetics of products and integration of the findings in a proposed intelligent design system. Journal Of Material Processing Technology, 153-154, 380-385.

Saito, Y. (2007). Everyday aesthetics. Oxford: Oxford University Press.

Sepänmaa, Y. (1980). Tarkoituksenmukaisuus ympäristön kauneuden kriteerinä. In A. Kinnunen \& Y. Sepänmaa (Eds.), Ympäristöestetiikka (Pp.199229). Helsinki: Gaudeamus.

Sepänmaa, Y. (1991). Kauneuden käsite \& ympäristö kokonaistaideteoksena. Technical Research Centre in Finland, Research Notes 1294, Espoo.

Shusterman, R. (1997). Taide, elämä ja estetiikka. Pragmatistinen filosofia ja estetiikka. (Translation Vesa Mujunen). Helsinki: Gaudeamus \& Finnish University Press.

Sircello, G. (1975). A new theory of beauty. Princeton: Princeton University Press.

Tiger, L. (1992). The pursuit of pleasure. Boston: Little, Brown \& Company. 
Uotila M. (1995). Image of clothing - the ways of being. In U. Suojanen (Ed.) Clothing and its social, psychological, cultural and environmental aspects. Proceedings of textiles, clothing and craft design, Helsinki, May 18-20, 1995 (pp. 93-105). University of Helsinki.

Walker, S. (2009). After taste - the power and prejudice of product appearance. The Design Journal, 12(1), 25-39.

\section{BIOGRAPHY}

Kirsi Niinimäki is a Post Doc Researcher at Aalto University, School of Arts, Design and Architecture. She focuses on design for sustainability issues, strategic sustainability approaches and green business thinking in her research. She has published in the Research Journal of Textile and Apparel, Journal of Sustainable Development, Design Journal, Journal of Cleaner Production, International Journal of Fashion Design, Technology and Education, and Journal of Textile Design Research and Practice.

\section{CORRESPONDENCE}

Kirsi Niinimäki

Aalto University, School of Arts, Design and

Architecture

Department of Design, Design Research

PO BOX 31000

FI-00076 Aalto

email: kirsi.niinimaki@aalto.fi

Tel +358405539414

Published online 31 December, 2014

ISSN 1749-3463 print/ISSN 1749-3471

DOI: 10.14434 /artifact.v3i3.3653

(C) 2014 Artifact 